\title{
Charakteristiky dobré základní školy z pohledu rodičů ${ }^{1}$
}

\author{
Jaroslava Simonová \\ Univerzita Karlova v Praze, Pedagogická fakulta, Ústav výzkumu a rozvoje vzdělávání
}

Redakci zasláno 3. 5. 2016 / upravená verze obdržena 13. 12. 2016 /

k uveřejnění přijato 19. 12. 2016

\begin{abstract}
Abstrakt: Přes poměrně velké množství prací, které se v mezinárodním kontextu věnovaly zkoumání rodičovských preferencí, neexistuje univerzální shoda na tom, co je pro rodiče při výběru školy nejdůležitější. Obvykle si rodiče cení výsledků vzdělávání, socioekonomického složení žáků, možnosti komunikace a zapojení do života školy nebo tříd s menším počtem žáků, sdílených hodnot a stylu výuky. Cílem stati je popsat charakteristiky dobré školy z pohledu českých rodičů s využitím dat získaných v longitudinálním šetření CLoSE od reprezentativního vzorku 2008 rodičů dětí v předškolním věku, a to pomocí obsahové analýzy a deskriptivních statistik, a porovnat informace zjištěné metodou otevřeného a uzavřeného dotazování. Rodiče očekávají, že škola bude poskytovat jim a jejich dětem individualizovaný př́stup orientovaný nejenom na dobré vzdělávací výsledky, ale především na co nejlepší kvalitu života, a umožní jim podílet se na utváření podoby školního vzdělávání svých dětí.
\end{abstract}

Klíčová slova: volba školy, základní škola, primární vzdělávání, obsahová analýza

\section{Vymezení zkoumané problematiky a teoretická východiska}

V České republice mají rodiče právo vybrat si základní školu, do které bude jejich dítě docházet. Právo volby je dáno školským zákonem, podle kterého žák plní povinnou školní docházku v základní škole se sídlem ve školském obvodu, v němž má místo trvalého pobytu (tato škola je označována jako spádová škola), pokud zákonný zástupce nezvolí jinou než spádovou školu (Zákon č. 561/2004 Sb., 2004).

Volba školy je v zahraničí vnímána především jako jeden z nástrojů pro zlepšování kvality vzdělávání. Teoretická východiska výběru školy vycházejí z ekonomických teorií o důsledcích konkurence a byla již v padesátých letech minulého století popsána americkým ekonomem a nositelem Nobelovy ceny

$1 \quad$ Text je výstupem řešení projektu GA ČR Vztahy mezi dovednostmi, vzděláváním a výsledky na trhu práce: longitudinální studie (číslo P402/12/G130). 
za ekonomii Miltonem Friedmanem (Friedman, 1955). Ten předpokládal, že rodiče, kterým bude volba školy umožněna, budou vybírat a že hlavním kritériem výběru budou vzdělávací výsledky školy. Díky financování škol podle počtu žáků tak vzroste kompetice mezi školami, která umožní vyselektování škol s nejlepšími výsledky vzdělávání.

Tato představa zlepšování kvality škol prostřednictvím soutěže o žáka vychází z řady implicitních předpokladů na straně rodičů i škol. Mnohé z nich však nemusí být nutně naplněny. Idealizovaný model např́klad předpokládá, že rodiče se ve svých očekáváních výrazně neliší a že tedy mezi nimi existuje jakási sdílená představa o tom, jak vypadá kvalitní vzdělávání. K této sdílené představě kvalitního vzdělávání pak rodiče dokáží přiřadit charakteristiky školy, jež vypovídají o kvalitě vzdělávání, a jsou schopni tyto charakteristiky zjistit. Z nich pak dovedou vybrat ty, které jsou pro kvalitu vzdělávání nejdůležitější, a přiřadit jim v rozhodovacím procesu adekvátní váhu. Následně se rodiče rozhodují zcela racionálně a zohlední relevantní přínosy i náklady docházky do konkrétní školy. V případě rozpoznání kvality dostupných škol pak rodiče budou ochotni a schopni investovat do docházky do té z nich, která je kvalitnější.

Na straně školy idealizovaný model předpokládá, že škola o žáky soutěží, tedy že se aktivně snaží informace o své kvalitě zpř́ístupnit a zároveň přesvědčit rodiče, že se významně liší od další dostupné školy vykazující srovnatelné charakteristiky. To znamená, že škola musí disponovat vedením, které umí vytvořit škole dostatečně přitažlivé renomé.

Již brzy po zavedení možnosti volby školy řada studií ukázala, že teorie odůvodňující prospěšnost výběru školy nebyly vždy naplněny. Kromě ekonomů se tématu volby školy začaly věnovat i sociologové a vznikající práce popisovaly teorii i důsledky volby školy v širším kontextu. Kromě jednání rodičů se pozornost postupně obrátila i k jednání škol. Některé školy se různými strategiemi snažily vytvořit pro rodiče přitažlivou „iluzi dobrých výsledků" např́íklad tím, že odmítaly přijímat žáky se specifickými vzdělávacími potřebami nebo alespoň zajišt'ovaly jejich neúčast ve dnech, kdy se výsledky vzdělávání zjištovaly pomocí standardizovaného testování (podrobněji např. Jennings, 2010).

Přístup rodičů $\mathrm{k}$ volbě školy je obvykle vysvětlován teorií racionální volby (rational choice theory). Dle této teorie jsou rodiče racionálními aktéry, kteří 
se snaží maximalizovat prrínosy svého rozhodnutí díky tomu, že důkladně zváží potenciální přínosy a náklady předpokládané volby (Goldthorpe, 1996; Hatcher, 1998). Její operacionalizaci ovšem poněkud komplikuje poznání, že neexistují „univerzálně racionální“ volby, a to ani v rámci stejné společenské třídy. Někteří vzdělaní a dobře situovaní rodiče si spádovou školu „racionálně“ nevyberou, aby dítě chránili před nežádoucími vlivy, jiní si ji „racionálně“ vyberou právě proto, aby se dítě s nežádoucími vlivy setkalo a naučilo se jim čelit (Cucchiara, 2013). Někteří rodiče si školu vybírají na základě výsledků standardizovaného testování, jiní výsledky testů nepovažují za důležité. Domnívají se totiž, že průměrné výsledky spádové školy nejsou dostatečně prediktivní pro dítě ze střední třídy, které je nadprůměrně vybavené kulturním a sociálním kapitálem (Kimelberg, 2014). Podobně jako výsledky testování jsou rodiči zpochybňovány i výsledky inspekčního hodnocení (Kool \& Bekkers, 2016). Rodiče tedy spoléhají spíše na neformální zdroje ze svého okolí než na údaje poskytované z oficiálních pramenů (Ball \& Vincent, 1998).

Podle teorie reprodukce kulturního kapitálu (Bourdieu \& Passeron, 1977) jsou rodičovské volby utvářeny především příslušností rodičů ke specifické sociální vrstvě. Ta totiž do významné míry určuje rozsah a kvalitu kulturního a sociálního kapitálu, který mají rodiče k dispozici (např. Reay \& Lucey, 2000). Nicméně i mezi př́vrženci této skupiny teorií se vedou disputace týkající se operacionalizace kulturního kapitálu, jenž se v čase poměrně rychle proměňuje.

Obě teorie se tedy do sebe prolínají: všichni rodiče jsou do jisté míry racionální, ovšem v rámci hranic, které vymezuje jejich sociální pozice. Racionalita i sociální ohraničení jsou však do značného rozsahu proměnlivé, a proto relativně obtížně výzkumně uchopitelné. Samotný proces rozhodování je pak ovlivněn i specifickým místním kontextem (Raveaud \& van Zanten, 2007).

Dosud se debata o tom, zda možnost výběru školy přispívá ke zlepšování kvality škol a také nakolik ovlivňuje spravedlivý přístup ke vzdělávání v České republice, prakticky nevedla. Rizika, která výběr školy provázejí a která jsou předmětem zahraničních debat, se $\mathrm{v}$ širším diskurzu neobjevují. Pokud se o výběru školy mluví, mluví se o něm spíše jako o možnosti, která je nabízena rodičům a která je podporována i orgány státní správy. ${ }^{2}$

2 Např́klad v ř́jnu 2014 Ministerstvo školství, mládeže a tělovýchovy na svých webových stránkách zveřejnilo informaci o spuštění iPortálu České školní inspekce, který má sloužit k vyhledávání vyhovující školy podle preferovaných parametrů (MŠMT, 2014). 
Aby bylo možné zjistit, zda volba školy v ČR má vůbec potenciál přispět ke zvyšování kvality škol, je důležité znát ty vlastnosti školy, které rodiče při výběru školy vyhledávají. Období volby školy je v životě rodičů etapou, kdy se zvyšuje jejich citlivost k problematice vzdělávání. Vnějšími okolnostmi jsou donuceni provést velmi osobní a konkrétní rozhodnutí. To je přiměje uvažovat o otázkách, jež jsou pro ně na obecné úrovni obvykle zcela nezajímavé.

Dotazováním rodičů v tomto senzitivním období tedy zároveň vzniká unikátní př́ležitost využít jejich výpovědi pro formulování společenské poptávky vzhledem ke vstupům, procesům i výstupům školního vzdělávání a podrobit detailnějšímu zkoumání okolnosti, jež ovlivňují její podobu. Předkládaná studie představuje jeden z prvních kroků, který umožní podrobnější konceptualizaci vlastností školy, jež jsou pro rodiče důležité, a tím připraví východiska pro jejich další zkoumání ve specifických podmínkách ČR.

\section{Přehled dosavadních zjištění}

Přes poměrně velké množství zahraničních prací, které se věnovaly zkoumání rodičovských preferencí, neexistuje univerzální shoda na tom, co je pro rodiče při výběru školy nejvíce důležité. Mezi důvody patří především různě systémově upravené možnosti volby (ne všude si rodiče reálně mohou volit jakoukoliv školu), různé kulturní a sociální zázemí a tradice jednotlivých zemí, jistě ale také různá teoretická východiska jednotlivých výzkumníků a často i obtížně srovnatelné metodologické přístupy. I když se v úvodních částech statí autoři hlásí k obecnějším východiskủm, podrobnější cesta k operacionalizaci vybraných konceptů ani její konkrétní důvody mnohdy nejsou dostatečně podrobně popsány.

Při zkoumání preferencí rodičů ohledně volby školy se v zásadě používají dva základní metodologické přístupy. V tom prvním se výzkumníci rodičů různou formou ptají na to, které charakteristiky školy jsou pro ně důležité, a následně analyzují jejich explicitní výpovědi. Ve druhém přístupu se snaží jejich preference určit pomocí analýzy voleb, které rodiče již učinili. Zatímco první přístup volí především výzkumníci z oblasti sociálních věd, druhý přístup se uplatňuje spíše v ekonomických studiích.

Ekonomové se analýzou již provedených voleb mj. snaží předcházet námitce, že rodiče kvůli potřebě poskytnout sociálně žádoucí odpověd' své skutečné preference nevyjeví, případně že vyjmenují důvody, které nejsou významnými prediktory jejich chování. Počítají také s tím, že rodiče si svých skutečných 
pohnutek nemusí být vědomi, případně je mohou považovat za příliš samozřejmé, a i když se snaží odpovídat pravdivě, z různých důvodů pak neuvedou ty nejdůležitější důvody.

Jejich námitky jsou jistě v mnoha směrech relevantní, na druhou stranu analýza již učiněných voleb má také svá omezení. Zkoumané charakteristiky školy se obvykle redukují jenom na ty, které jsou snadno měřitelné a zároveň měřené (např́klad výsledky žákủ, jejich socioekonomický status, velikost školy, počet žáků ve třídě). Jiné faktory, které pro rodiče mohou být důležité, ale které je obtížné zjištovat či převádět do podoby proměnných, tak mnohdy zůstávají opomenuty.

Vypovídací hodnota výsledků dotazníkových šetření není omezena jenom výzkumníkovým výběrem charakteristik školy, na které se dotazuje, ale také způsobem, jakým se na ně táže. Výsledky studií, v nichž rodiče vybírali z nabídnutých charakteristik všechny ty, jež se jim jevily jako důležité, jsou jenom obtížně srovnatelné s těmi, ve kterých měli rodiče nabídnuté charakteristiky seřadit podle důležitosti, př́ípadně vybrat tři nejdůležitější. Ještě jiný obraz rodičovských preferencí pak poskytují výsledky kvalitativních šetření založených na rozhovorech a ohniskových skupinách.

Oba zmiňované př́ístupy jsou nicméně užitečné. Je totiž nutno rozlišovat „ideální" svět preferencí a „reálný“ svět možných voleb: i když si rodiče na začátku výběru mohou stanovit vlastnosti ideální školy, často se stává, že nenacházejí školy odpovídající jejich přáním, a nakonec si musí vybírat ze škol, které jsou dostupné, přičemž jejich vlastnosti mohou být od původních kritérií poměrně vzdálené.

Dosavadní výzkumy identifikovaly celé spektrum charakteristik školy, které rodiče považují za důležité. Rodiče obecně nejvíce oceňují výsledky vzdělávání (např. Schneider et al., 1998; Kleitz et al., 2000; Burgess et al., 2015), význam této charakteristiky se však může v různých podskupinách (dle socioekonomického zázemí, etnicity, náboženského vyznání apod.) lišit. Například ve dvou největších městech provincie Alberta (Kanada) byla pro rodiče ze všech typů škol důležitá akademická excelence, tedy výsledky standardizovaného testování (Bosetti \& Pyryt, 2007). Rodiče tomuto cíli nicméně přidělili různě velkou váhu v závislosti na typu školy, který si vybrali. Výsledky žáků v testování byly nejdůležitějším kritériem pro 75 \% rodičů vybírajících spádové školy, ale jenom pro 61 \% rodičů vybírajících jinou než spádovou školu a pouze pro 50 \% rodičů vybírajících soukromou školu. 
Rozpory v deklarovaných a realizovaných preferencích ilustruje například výzkum mezi chilskými rodiči vybírajícími základní školu, který uskutečnili Elacqua a de Gobierno (2004). Rodiče všech vzdělanostních kategorií měli velmi podobné preference a nejvíce si cenili dosažených výsledků vzdělávání. Pohled na školy, které si vybrali, ovšem jejich preference nepotvrdil. Vzdělávací výsledky ve zvažovaných školách se zásadně lišily, zatímco složení jejich žáků bylo velmi podobné, byt' rodiče neuváděli sociální složení žáků školy jako důležité kritérium. Neregulovaná volba školy tedy může redukovat tlak na zlepšování výsledků škol a zároveň zvyšovat tlak na to, aby školy „zlepšily“ složení svých žáků. K podobným výsledkům dospěli ve Washingtonu Schneider a Buckley (2002), kteří sledovali kritéria, jaká rodiče používali pro vyhledávání školy $\mathrm{v}$ on-line prostředí - demografické složení patřilo $\mathrm{k}$ těm nejvyhledávanějším navzdory faktu, že rodiče tuto skutečnost při přímém dotazování zdaleka nepřipouštěli v takové míře.

Kromě akademických kvalit rodiče oceňují klima školy, důraz na řád a disciplínu, zajímá je také počet žáků ve třídách, jejich sociální složení (Burgess et al., 2015), dále atraktivita prostředí školy a její pověst (Denessen, Driessena, \& Sleegers, 2005). Další výzkumy ukázaly, že důležitá může být poloha školy, která bývala podrobněji popisována různými způsoby, např́íklad jako blízkost (např. Goh, 2009), ale také dostupnost (Burgess et al., 2015), dále speciální zaměření kurikula a zájmové aktivity po vyučování (Schneider \& Buckley, 2002), spokojenost dítěte (Bussel, 1998), ale také bezpečí a přítomnost kamarádů (Kleitz et al., 2000). Roli může hrát i skutečnost, zda se jedná o církevní školu a jaké je její pojetí vzdělávání (Borghans, Golsteyn, \& Zölitz, 2015).

Zodpovědný výběr školy je poměrně náročný úkol, který vyžaduje dovednosti a zdroje, jimiž nedisponují všechny rodiny ve srovnatelné míře. Právě dostupnost zdrojů do značné míry určuje, jak se rodiče orientují v nabídce škol (např. Ball \& Vincent, 1998). Zástupci střední třídy jsou obvykle vybavenější po stránce materiální i sociální. Typickými demografickými prediktory výběru školy jsou vyšší socioekonomický status rodičů, reprezentovaný nejčastěji vzděláním rodičů (např. Davies \& Aurini, 2011) a jejich př́jmem (např. Hastings, Kane, \& Staiger, 2005). Míra zapojení do výběru školy a důvody pro volbu konkrétní školy mohou být predikovatelné také z postojů rodičủ (např. postoj k právu vybírat si školu) nebo z jejich předešlého chování (např́klad dle míry spolupráce rodiny se školou), přičemž angažovaní rodiče jsou umožněním volby „odčerpáváni“ z běžných veřejných škol, čímž jsou tyto školy ochuzovány o klíčový zdroj (Davies \& Aurini, 2011). 
Obraz, který výsledky výzkumů vytvářejí, není úplně jednoznačný. Obecně děti bohatších a vzdělanějších rodičủ mají větší šanci na to, že jejich rodiče pro ně budou školu vybírat. Jednotliví autoři se však liší v tom, čeho si bohatší a vzdělanější rodiče cení nejvíce. $V$ některých případech jsou to výsledky žáků v testování (např. Hastings et al., 2005; Goh, 2009), důležité je ale také socioekonomické složení žáků (Burgess et al., 2015), snadnější možnost komunikace a zapojení do života školy (Goldring \& Phillips, 2008) nebo tř́́dy s menším počtem žáků, sdílené hodnoty a přesvědčení a styl výuky (Bosseti, 2004).

Borghans a kol. (2015) rovněž upozornili na to, že preference rodičů obvykle nejsou jednodimenzionální, a rodiče při výběru tedy zohledňují více charakteristik. Když pak rodiče mají nízké preference týkající se kvality školy vzhledem k ostatním charakteristikám, tlak na kvalitu zůstává malý, i když rodiče mají více možností vybírat. $V$ takovém případě volba školy může stimulovat spíše specializaci škol pomocí nabídky specifických programů místo zlepšování jejich kvality.

\section{Cíle, data a metodologie výzkumného šetření}

\subsection{Cíle}

Hlavním cílem výzkumu bylo odpovědět na výzkumnou otázku, jaké charakteristiky školy považují rodiče dětí za důležité. Dalším cílem pak bylo porovnat informace zjištěné metodou otevřeného a uzavřeného dotazování. Položení otevřené otázky umožnilo zhodnotit, zda se nezačínají objevovat takové aspekty základní školy, které v uzavřené otázce nebyly zahrnuty.

\subsection{Respondenti}

Pro analýzu byla použita data z longitudinálního dotazníkového šetření CLoSE (Czech Longitudinal Study in Education). Šetření se účastnilo 2008 rodičů dětí předškolního věku. Rodiče dětí v posledním roce předškolní docházky jsme vybrali náhodným dvoustupňovým výběrem. Nejdříve bylo z databáze mateřských škol náhodně vybráno 95 škol. Poté došlo v každé vybrané mateřské škole $\mathrm{k}$ náhodnému výběru jedné předškolní třídy nebo předškoláků $\mathrm{z}$ různých tříd v případě, že třídy byly věkově heterogenní. Dotazníky vyplnily v 87 \% matky. Výsledný soubor lze považovat za reprezentativní 
vzhledem $\mathrm{k}$ populaci rodičů předškoláků jak z hlediska velikosti obce, tak z hlediska vzdělanostní struktury. ${ }^{3,4}$

Popisné charakteristiky výběrového souboru uvádí tabulka 1.

Tabulka 1

Popisné charakteristiky výběrového souboru v první vlně šetření rodičovské populace CLoSE 2014

\begin{tabular}{lcc}
\hline Nejvyšší dosažené vzdělání rodiče vyplňujícího dotazník & $\mathrm{N}$ & $\%$ \\
\hline Základní bez vyučení & 64 & 3,2 \\
Vyučen(a) bez maturity & 428 & 21,6 \\
Středoškolské s maturitou & 942 & 47,5 \\
Vysokoškolské & 549 & 27,7 \\
Celkem & 1983 & 100 \\
\hline Nejvyšśí dosažené vzdělání druhého rodiče & & \\
\hline Základní bez vyučení & 64 & 3,3 \\
Vyučen(a) bez maturity & 747 & 38,1 \\
Středoškolské s maturitou & 670 & 34,2 \\
Vysokoškolské & 478 & 24,4 \\
Celkem & 1959 & 100 \\
\hline Velikost sídla & & \\
\hline Méně než 5000 obyvatel & 730 & 37,6 \\
5 000-19 999 obyvatel & 517 & 26,6 \\
20 000-99 999 obyvatel & 343 & 17,7 \\
Více než 100 000 obyvatel & 349 & 18,0 \\
Celkem & 1939 & 100 \\
\hline
\end{tabular}

\subsection{Metoda sběru dat}

Rodiče předškolních dětí obdrželi dotazníky obsahující otázky týkající se výběru MŠ, zvažování odkladu, výběru ZŠ a otázky zjištující charakteristiky dítěte a jeho rodiny. Dotazníky administrovala agentura STEM-MARK v jarních měsících roku 2014. Rodiče je vyplňovali metodou tužka-papír. Dotazník zahrnoval i otevřenou otázku (čtrnáctá v pořadí) a uzavřenou otázku (dvacátá první), které se zaměřovaly na výběr školy. $V$ otevřené otázce měli rodiče odpovídat na dotaz: Co musí splňovat dobrá škola pro Vaše dítě? Napište prosím

3 Srovnáno s daty ze Sčítání lidu, domů a bytů 2011.

4 Srovnáno s věkovou skupinou 30-44 let z výzkumu OECD PIAAC (2012). 
ty nejdůležitější věci, které se Vám vybaví. V uzavřené otázce jsme rodičům předložili různé vlastnosti školy, které mohou být důležité při rozhodování o výběru, a požádali je, aby u každé $\mathrm{z}$ nich uvedli, do jaké míry je pro ně důležitá na stupnici od 1 = velmi důležité do $4=$ zcela nedůležité. Rodiče si mohli vybírat z následujících vlastností školy: moderní, hezké prostredí; vybavení moderní technikou a učebními pomůckami, učebnami; dobrá pověst školy, prestiž; přátelská atmosféra, vlídné prostredí, př́jemní učitelé; nároční učitelé; kvalitní stravování pro žáky; ochota a schopnost učitelu zohlednit individuální potřeby jednotlivých žáků; atraktivní, zajímavý způsob výuky; počet žáků ve tř́idě, velikost školy; nabídka a zázemí pro využití volného času, sportovní či kulturní vyžití; kvalitní výuka cizích jazyků; složení žáků ve škole; poloha školy; jiné (vypište).

Ve srovnání s otázkami s výběrem odpovědi klade položení otevřené otázky značné nároky na zpracování, proto není využívána tak často jako uzavřené otázky. Na druhou stranu získané odpovědi nejsou zatíženy předvýběrem možných charakteristik školy ze strany výzkumníků, a mohou proto lépe reprezentovat skutečné názory respondentů.

Míra návratnosti dotazníků byla 49,5\%. Na otevřenou otázku odpovědělo 1384 rodičů, tedy $68,9 \%$ z těch, kteří dotazník vyplňovali.

\subsection{Analýza dat}

Pro analýzu odpovědí na uzavřenou otázku byly použity deskriptivní statistické metody. Pro analýzu odpovědí na otevřenou otázku byla použita obsahová analýza, která je v širším slova smyslu považována za „repertoár metod výzkumu, které slibují získat závěry ze všech typů verbálních, obrazových, symbolických a komunikačních dat" ${ }^{5}$ (Krippendorff, 2014, s. 23). V českém prostředí vyčerpávající přehled různých podob a možností obsahové analýzy recentně nabídl Gavora (2015). Obsahová analýza může být používána deduktivním způsobem pro ověření platnosti již existujících teorií (například pro jinou populaci), nebo induktivně - pro vytváření hypotéz a nalézání nových konceptů a zákonitostí v datech (Elo \& Kyngas, 2008).

Tématu volby školy je v zahraničí věnována dostatečná pozornost a je dostupných několik teorií, které umožňovaly použití deduktivního přístupu. Ze základních charakteristik českého vzdělávacího systému a také z předchozích

5 Znění v originále: „a repertoire of methods of research that promise to yield inferences from all kinds of verbal, pictorial, symbolic, and communication data". 
výzkumů bylo ovšem patrné, že tradiční kategorie nejsou pro české rodiče zcela relevantní. Např́íklad data o kvalitě školy na základě plošných testů nebyla ještě donedávna $\mathrm{v}$ ČR dostupná, takže toto základní kritérium jsem nemohla uplatnit. Proto byl po úvodním zhodnocení dat zvolen induktivní přístup. Ten také odpovídá předpokladu, že očekávání rodičů se mohou $\mathrm{v}$ čase proměňovat, a tedy může být užitečné nevycházet pouze $\mathrm{z}$ dosavadních teorií a zjištění.

I když řada publikací nabízí žádoucí posloupnost kroků, které by měly při použití designu obsahové analýzy proběhnout (např. Plichtová, 1996; Neuendorf, 2002; Gavora, 2015), bylo obtížné rozhodnout se, který design je nejvhodnější. Jak poznamenávají Elo a Kyngas (2008), obsahová analýza je velmi flexibilní a neexistuje jediný „správný“ způsob, jak ji provádět. Při rozhodování o způsobu provedení je potřeba zohlednit nejenom teoretická východiska, ale také výzkumnou otázku a charakter dat.

Jednotkami sběru dat byly výpovědi jednotlivých rodičů. Získané odpovědi se lišily v délce i komplexnosti. Celé věty se objevovaly výjimečně, významná část byla tvořena jedním nebo několika slovními spojeními, například: vzdělávání dětí, hodné učitelky, informovanost, sportovní aktivity, individuální př́stup $k$ žákům. Výpovědi rodičů byly dále rozděleny na jednotky analýzy. Jednotku analýzy představovalo slovní spojení označující vlastnosti školy, například vzdělávání dětí nebo hodné učitelky.

Nejdřív byly pomocí otevřeného kódování vytvořeny primární kódy. To znamená, že jednotkám analýzy byly přiděleny kódy vzešlé z otevřeného kódování. Ty byly postupně upravovány, rozšiřovány či zužovány a redefinovány tak, aby plně zachycovaly šiři dat a aby zároveň umožnily přiřadit každé jednotce analýzy právě jeden kód. Tak vznikl systém kódů. Posléze byly tyto kódy organizovány do kategorií, které zachycovaly význam několika kódů. $\mathrm{V}$ průběhu analýzy byly jednotky analýzy opakovaně srovnávány s identifikovanými kategoriemi v iterativním procesu, který měl zajistit, aby významy, které text obsahoval, zůstaly konzistentní (Hsieh \& Shannon, 2005). Po induktivním vynoření kódů byly výpovědi rodičů analyzovány deduktivně: ve vytvořeném systému kódů byla výpovědi rodiče přidělena hodnota 1 $\mathrm{v}$ případě, že výpověd' rodiče obsahovala datový úryvek, který bylo možné zahrnout pod vybraný kód. ${ }^{6}$

6 Např́klad k jednotce analýzy kvalitní učitelky, dobrá komunikace s rodiči, přátelské prostředí byla přiřazena hodnota 1 kódům „učitelé“, „komunikace s rodiči“ a „well-being“. 


\section{$4 \quad$ Výsledky}

Z analýzy dat otevřené otázky věnované vlastnostem, které rodiče očekávají od dobré školy, vzešlo pět hlavních kategorií vlastností školy, které jsou pro rodiče důležité: pozice školy, péče mimo vyučování, poskytování kvalitního vzdělávání, zajištění kvality života a zajištění vlivu. Tabulka 2 uvádí přiřazení jednotlivých kódů do kategorií.

Tabulka 2

Přehled kódů a kategorií vymezujících charakteristiky dobré školy

\begin{tabular}{|c|c|c|c|}
\hline Kategorie & Kód & Popis & Př́íklad \\
\hline \multirow[b]{2}{*}{ Pozice školy } & Dostupnost & $\begin{array}{l}\text { pozice školy ve fyzicko- } \\
\text { geografickém smyslu }\end{array}$ & $\begin{array}{l}\text { snadná dostupnost pro dítě; dobrá } \\
\text { poloha }\end{array}$ \\
\hline & Pověst & $\begin{array}{l}\text { renomé školy, } \\
\text { zprostředkované sociální } \\
\text { skupinou, ve které se rodič } \\
\text { pohybuje }\end{array}$ & $\begin{array}{l}\text { dobrá pověst školy; dobré reference; } \\
\text { recenze školy; doporučení rodičů }\end{array}$ \\
\hline \multirow{3}{*}{$\begin{array}{l}\text { Péče mimo } \\
\text { vyučování }\end{array}$} & Družina & $\begin{array}{l}\text { zajištění péče o dítě v době } \\
\text { mimo vyučování }\end{array}$ & školní družina \\
\hline & Kroužky & $\begin{array}{l}\text { možnosti rozvoje dítěte } \\
\text { v době mimo vyučování }\end{array}$ & dostatečný výběr kroužků \\
\hline & Jídelna & zajištění stravování & $\begin{array}{l}\text { možnost kvalitního stravování; } \\
\text { zdravé stravování }\end{array}$ \\
\hline \multirow{4}{*}{$\begin{array}{l}\text { Poskytování } \\
\text { kvalitního } \\
\text { vzdělávání }\end{array}$} & Výuka & $\begin{array}{l}\text { realizované kurikulum, } \\
\text { včetně metod }\end{array}$ & $\begin{array}{l}\text { dobrá kvalita vyučování; cizí jazyky } \\
\text { od 1. třídy; kvalitní vzdělávání } \\
\text { zábavnou formou }\end{array}$ \\
\hline & Výstupy & $\begin{array}{l}\text { kognitivní i nekognitivní } \\
\text { výsledky vzdělávání }\end{array}$ & $\begin{array}{l}\text { výsledky žákủ při přijímacím řízení } \\
\text { na další stupeň vzdělávání; naučit } \\
\text { dítě samostatnosti }\end{array}$ \\
\hline & Učitelé & $\begin{array}{l}\text { charakteristiky učitelů } \\
\text { a vedení školy }\end{array}$ & $\begin{array}{l}\text { kvalifikovaní učitelé; psychicky } \\
\text { odolné učitelky }\end{array}$ \\
\hline & Vybavení & technika, pomůcky & $\begin{array}{l}\text { dobré technické vybavení; } \\
\text { vybavenost pomůckami; kvalitní } \\
\text { učebnice }\end{array}$ \\
\hline \multirow[t]{2}{*}{$\begin{array}{l}\text { Zajištění } \\
\text { kvality } \\
\text { života }\end{array}$} & Well-being & $\begin{array}{l}\text { specifické charakteristiky } \\
\text { fyzického prostředí, } \\
\text { pedagogů a probíhajících } \\
\text { procesů vedoucí k vytvoření } \\
\text { fyzicky a mentálně } \\
\text { př́ijemného prostředí }\end{array}$ & $\begin{array}{l}\text { hodné paní učitelky; vstřícnost; } \\
\text { dobrý přístup k dětem; přátelské } \\
\text { prostředí }\end{array}$ \\
\hline & $\begin{array}{l}\text { Individuální } \\
\text { př́stup }\end{array}$ & $\begin{array}{l}\text { zohlednění individuálních } \\
\text { potřeb dítěte }\end{array}$ & $\begin{array}{l}\text { nižší počet žáků ve třídě; } \\
\text { individuální přístup učitele k žákům }\end{array}$ \\
\hline \multirow{2}{*}{$\begin{array}{l}\text { Zajištění } \\
\text { vlivu }\end{array}$} & $\begin{array}{l}\text { Komunikace } \\
\text { s rodiči }\end{array}$ & zajištění výměny informací & $\begin{array}{l}\text { komunikace vedení a učitelek } \\
\text { s rodiči }\end{array}$ \\
\hline & $\begin{array}{l}\text { Spolupráce } \\
\text { s rodiči }\end{array}$ & $\begin{array}{l}\text { vyvíjení společně } \\
\text { zaměřeného úsilí }\end{array}$ & úzká spolupráce s rodiči \\
\hline
\end{tabular}


Přehled o četnostech a procentuálním zastoupení výskytů jednotlivých kódů ve výpovědích rodičů udává tabulka P1, která je uvedena v př́loze.

\section{Pozice školy}

Pro rodiče je důležitá pozice školy ve fyzicko-geografickém i socio-kulturním významu. Z organizačního hlediska je podstatné, $v$ jaké vzdálenosti se škola nachází vzhledem $\mathrm{k}$ bydlišti dítěte a jak je dostupná - bud' přímo pro dítě, nebo z hlediska dopravního zajištění rodiči (hlavně aby byla nejbliže domova; dopravní dostupnost; dostupnost MHD; bezpečná cesta ${ }^{\top}$. Rodiče hledají školu $\mathrm{v}$ př́ijemném prostředí, v klidné a bezpečné lokalitě (bezpečnost kolem školy; čisté a klidné prostředî). Důležitá je ale také pověst školy, tedy její renomé (kladné reference; dobrá pověst; recenze školy; prestiž školy). Pro rodiče, kteří pověst školy uvádějí jako důležité kritérium, je tedy důležité sociální „schválení", protože renomé školy lze charakterizovat jako sdílený úsudek o kvalitě školy, vytvořený širším společenstvím sídla - např. dobré ohlasy rodiču od dětí každého věku (1.+2. stupeň). Tito rodiče nespoléhají pouze na vlastní úsudek, ale hledají informace v sociální skupině, která je pro ně relevantní (celkový dojem ze školy a její doporučení kamarádů co zde mají děti). Rodiče tyto informace sdílejí ve svých sociálních sítích, a proto se renomé dané školy může měnit v souvislosti se zaměřením a prioritami sociální skupiny, ze které rodiče pocházejí (dobré reference od známých).

\section{Péče mimo vyučování}

Rodiče potřebují, aby o jejich dítě bylo co nejlépe postaráno $v$ době, kdy už vyučování neprobíhá a kdy péči nemohou nebo nechtějí zajišt'ovat osobně. Odtud primárně pramení zájem o stravování (kvalita stravování; zdravé stravování; dobré stravovací podmínky) a zajištění péče v době mimo vyučování, at' už formou družiny nebo kroužků (prostorná a vybavená družina; zázemí využití volného času; možnost výběru zájmových kroužků). Potřeba zajistit péči mimo vyučování ukazuje, že rodiče školu zdaleka nechápou pouze jako místo ke vzdělávání, ale také jako instituci, která zajištuje trávení volného času dětí. Přání rodičů zajistit volnočasové aktivity prostřednictvím školy lze také interpretovat jako zárodek poptávky po komunitním charakteru školy.

Výroky rodičů uvádíme $\mathrm{v}$ autentickém znění bez jazykových úprav. Výroky jednotlivých rodičů jsou odděleny středníky. 


\section{Poskytování kvalitního vzdělávání}

Rodiče mají nepochybně zájem o to, aby jejich dítěti bylo poskytováno co nejkvalitnější vzdělávání. Jejich očekávání jsou dle naturelu rodičů formulována poměrně různě. Rodiče zmiňují vybavení školy (moderní učebny, pomůcky; přehledné učebnice; optimální vybavení $k$ výuce), obsah vzdělávání (všeobecný rozhled; učí děti uvažovat, logicky myslet, rozvíjí je, neučí je jen biflovat; zajistit dostatečné vzdělání pro výběr povolání; rozvíjení schopnosti řešit samostatně úkoly, vyhledávat a zpracovávat informace, vést diskusi, spolupracovat), metody vzdělávání (klasické hodnocení; učení škola hrou; zásady Komenského; přirozené podporování zvídavosti dětí; dostatečné ocenění úspěchu žáka), výsledky vzdělávání (dobré výsledky v plošných testech; úspěšnost žáků - absolventů při přijímacích řízeních na navazující školy; naučit číst, psát a počítat; naučitje základním znalostem; naučit co má - učit se, chování; zvládnutí učiva, chování $v$ kolektivu, poznání svých kvalit i slabin a jejich řešení, odpovědnost, samostatnost) i kvalifikaci pedagogického sboru (kvalifikovaní učitele). I když se představy rodičů o tom, jak vypadá kvalitní vzdělávání, mohou poměrně zásadně lišit, je zjevné, že na kvalitě vzdělávání jim záleží. Je ovšem zřejmé, že představa o charakteristikách kvalitního vzdělávání zdaleka není konsenzuální. Co některé rodiče přitahuje, jiní mohou považovat za nežádoucí (např. škola hrou vs. klasické hodnocení). Tato inkoherence pak v průběhu docházky do školy může vyvolávat tenze mezi různými rodiči a mezi rodiči a učiteli.

Rodiče relativně málo strukturovaně vyjadřují své představy o tom, co by se dítě mělo ve škole naučit, zmiňují například specifické zaměření (nejčastěji na jazyky a sport). Obsáhlejší jsou jejich vyjádření k používaným metodám výuky. $\mathrm{V}$ některých případech obecně požadují moderní způsob vyučování (týmová spolupráce místo normální výuky), uvádějí výčet očekávaných metod (výlety a exkurze), případně uvádějí konkrétní alternativní směry vzdělávání (Montessori prvky; výuka formou projektového a tzv. problémového vyučovánî). V oblasti výstupů vedle očekávatelných kognitivních výstupů, popsaných bud' obecně jako výsledky, nebo jako př́prava na príijímací zkoušky, hrají důležitou roli i nekognitivní výstupy komplexnějšího charakteru (např. samostatnost, socializace, schopnost plnit si povinnosti aj.).

\section{Zajištění kvality života}

Rodiče si přejí, aby kvalita života jejich dětí v průběhu pobytu ve škole byla co možná nejvyšší. V centru jejich pozornosti nestojí jenom to, co se dítě bude učit a jak se to bude učit, chtějí také, aby se ve škole cítilo co nejlépe (aby se 
tam dětem líbilo a těšily se do školy). Chtějí, aby jejich dětem ve škole nikdo neubližoval, aby k nim učitelé byli vstřícní a nepřetěžovali je a aby ve třídě měly kamarády (př́stup $k$ dětem, aby dítě nebylo stresováno a chodilo rádo do školy; kamarádství bez šikany a v prípadě náznaku to ihned co nejlépe řešila). Od pedagogického sboru rodiče očekávají, že učitelé budou manifestovat postoje, které zajistí dětem pocit bezpečí, osobní pohody a budou je přiměřeně a pozitivně stimulovat (respekt $k$ dítěti; bezpečné klima, prátelská a otevřená atmosféra mezi žáky, rodiči a učiteli; aby se tam děti cítili dobře a nebáli se tam chodit). Předpokládají, že kvalita interakce mezi učitelem a žákem bude zaměřena primárně na well-being žáka (schopné, a hlavně hodné učitele, kteř́ by měli svým chováním a př́stupem $k$ dětem namotivovat děti, aby se jim ve škole i nadále líbilo a učení je bavilo). Je pro ně tedy důležitá jeho osobní pohoda, která implicitně zahrnuje duševní, tělesnou i sociální dimenzi (Kebza \& Šolcová, 2005).

Pro rodiče je podstatný nejenom kognitivní a sociální rozvoj dítěte, ale i celková kvalita jeho života, jíž je osobní pohoda nedílnou součástí (Costanza, 2007). Rodiče očekávají klidné, vlídné, vstřícné, trpělivé, tolerantní a spravedlivé jednání, $\mathrm{v}$ jehož důsledku bude pro dítě pobyt ve škole zajímavý, podnětný a smysluplný (dítě by mělo chodit do školy rádo, naučit se plnit povinnosti, nemělo by být pretetěžováno, čímž by ztratilo zájem, je důležité získat kladný vztah k učení, pro další vzdělávání). Vedle kognitivních dovedností učitelů tedy vyjmenovávají poměrně široké spektrum nekognitivních charakteristik, které mají významný vliv na utváření školního klimatu (př́ijemní učitelé; hodné učitelky; vlídný a milý přístup učitelek; vřelý přístup učitelů k žákům; porozumění ze strany učitelu; srdečný přístup; klidní učitelé; ochota pomoci, pokud dítě nestíhá; chápající personál; vstřícný př́stup učitelů). Zároveň očekávají, že škola a její bezprostřední okolí bude mít takové fyzické atributy, které budou přispívat $\mathrm{k}$ vytváření př́jemného prostředí a žádoucího klimatu (hezké prostředí; čisté klidné prostředí). Dalším projevem zaměření na celkovou pohodu dítěte je zájem o nižší počty žáků ve třídě (počet dětí ve tř́dě max 17; málopočetné třídy) a přítomnost kamarádů a spolužáků z mateřské školy, mít kolem sebe kamarády (nejlépe ty ze školky), v některých př́ípadech rodiče zajímá i složení žáků, například ve vztahu k etnicitě nebo speciálním vzdělávacím potřebám (minimální počet romských spolužáků; minimum problémových dětí; nesmí zde nepřizpůsobiví a sociálně slabí dělat problémy). 


\section{Zajišt'ování vlivu}

Důležitou součástí zajištování kvality ve všech výše zmíněných oblastech je uplatňování vlivu. Mnozí rodiče nechtějí být jenom pasivními konzumenty služeb, které škola poskytuje, chtějí být také jejich spolutvůrci a vztah mezi rodinou a školou je pro ně důležitý. V nejjednodušší podobě rodiče projevují zájem o poskytování informací (informovanost; kontakt s rodiči), další ovšem mají zájem výslovně o komunikaci, která předpokládá přenos informací a názorů nejenom od školy k rodičům, ale také od rodičů ke škole (otevřená komunikace mezi učitelem a rodiči; neautoritativní komunikace s rodiči; ochota pracovat s návrhy rodičů). Další stupeň pak tvoří navázaní partnerského vztahu, který zdůrazňuje rovnocenné postavení rodičů a učitelů (úzká spolupráce a komunikace s rodiči; partnerský vztah škola x rodiče). Další rodiče mají zájem o aktivní zapojení, prezentovaný jako zájem o spolupráci - někteří předjímají vznik problémů, ale zároveň očekávají, že na jejich řešení budou pracovat v dialogu s učiteli (spolupráce školy s rodiči; otevřený př́stup $k$ řešení problémů; otevřenost $k$ možným problémům s možností porady; kooperace $s$ rodiči při řešení problémů).

Kvalitativní analýza otevřené otázky přinesla informace o tom, které aspekty školy rodiče považují za důležité, nicméně z ní není patrné, jak důležité pro ně jsou, tedy jakou jim připisují váhu. Tyto informace můžeme čerpat $\mathrm{z}$ odpovědí na uzavřenou otázku, které jsou shrnuty v tabulce 3 . V prvním sloupci tabulky je uvedeno procento rodičů, kteří danou charakteristiku označili jako velmi důležitou, ve druhém sloupci pak průměrné hodnocení na škále 1 = velmi důležité do 4 = zcela nedůležité, které více vypovídá o její celkové důležitosti, a v posledním sloupci je uvedená směrodatná odchylka, která ilustruje rozptyl odpovědí.

Rodiče si nejvíce cení vlídného prostředí a příjemných učitelů, v jistém odstupu následuje ochota a schopnost učitelů zohlednit individuální potřeby žáků. Srovnatelnou pozornost pak věnují pověsti školy, kvalitní výuce jazyků a metodám výuky. Nejméně si rodiče cení náročných učitelů, které považuje za důležité jenom necelá pětina rodičů. Zdá se tedy, že rodiče připisují větší důležitost celkové kvalitě života svého dítěte $v$ průběhu pobytu ve škole než těm charakteristikám školy, které o škole vypovídají z hlediska nároků na výsledky vzdělávání. 
Tabulka 3

Charakteristiky školy, které jsou důležité pro rozhodování rodičů

\begin{tabular}{lccc}
\hline & $\begin{array}{c}\text { \% velmi } \\
\text { důležité }\end{array}$ & Průměr & SD \\
\hline Přátelská atmosféra, vlídné prostředí, příjemní učitelé & 90,5 & 1,11 & 0,35 \\
Ochota a schopnost učitelů zohlednit individuální potřeby & 75,7 & 1,28 & 0,53 \\
jednotlivých žáků & 59,2 & 1,47 & 0,61 \\
Dobrá pověst školy, prestiž & 58,5 & 1,47 & 0,61 \\
Kvalitní výuka cizích jazyků & 58,3 & 1,48 & 0,61 \\
Atraktivní, zajímavý způsob výuky & 46,4 & 1,63 & 0,67 \\
Kvalitní stravování pro žáky & 45,4 & 1,61 & 0,61 \\
Vybavení moderní technikou a učebními pomůckami, učebnami & 41,2 & 1,72 & 0,71 \\
Nabídka a zázemí pro využití volného času, sportovní či & 38,6 & 1,85 & 0,84 \\
kulturní vyžití & 37,1 & 1,82 & 0,76 \\
Poloha školy & 25,4 & 2,13 & 0,88 \\
Počet žáků ve třídě, velikost školy & 23,1 & 1,93 & 0,64 \\
Složení žáků ve škole & 17,2 & 2,13 & 0,74 \\
\hline Moderní, hezké prostředí & & & \\
Nároční učitelé
\end{tabular}

\section{Diskuse}

Očekávání rodičů v souvislosti se zahájením povinné školní docházky signalizují, že pro stále významnější část rodičů je kvalita interakce mezi učitelem a dítětem srovnatelně důležitá jako poskytování kvalitního vzdělávání a výrazně důležitější než výsledky vzdělávání.

Když rodiče poptávají primárně kvalitu interakce, nemusí to nutně znamenat, že je pro ně důležitější než kvalita vzdělávání. Spíš se přikláníme k názoru, že kvalitu interakce poptávají především proto, že považují nabízenou či poskytovanou kvalitu př́istupu učitelů k dětem za nedostatečnou. Rodiče se celkem mohou spolehnout na to, že jejich dítě se v první třídě naučí základní trivium. Daleko méně se ale mohou spolehnout na to, že pobyt ve škole bude pro jejich dítě př́ijemný. Proto mohou cítit větší potřebu vyjadřovat svá přání ohledně kvality života dítěte ve škole než ohledně kvality jeho vzdělávání.

To je zvláště pochopitelné v situaci, kdy je část komunikujících rodičů vnímána jako rodiče (přehnaně) aktivní, jejichž způsob komunikace není školou vnímán pozitivně (Rabušicová, 2004), a také proto se nemohou spolehnout 
na to, že případné problémy budou uspokojivě řešeny. I Česká školní inspekce (Šojdrová, Swart, \& Gabal, 2013) ve zprávě z realizace projektu Překonávání školního neúspěchu v České republice upozorňuje, že komunikace školy s rodiči může představovat slabinu některých škol, protože až $40 \%$ rodičů dostává informace ze školy jednou za čtvrt roku nebo ještě méně často, a poukazuje na nutnost posílení komunikace škol s rodiči.

Na tento trend upozornila i analýza otevřené otázky, která ukázala poptávku rodičů po komunikaci a spolupráci se školou. Část rodičů vyjádřila přání aktivně vstupovat do dialogu s učiteli a partnersky přistupovat $\mathrm{k}$ řešení problémů. Rodiče tedy chtějí mít aktivní podíl na utváření vzdělávání svých dětí. I když obecně panuje se školstvím i s komunikací se školou spokojenost (Walterová et al., 2010), rodiče, kteří nejsou spokojeni, zajišt’ují svým dětem přestup a ve výjimečných případech zakládají své vlastní školy. Tyto trendy můžeme sledovat $\mathrm{v}$ mnoha systémech, které umožnily rodičovské angažmá ve školství (např. charter schools v USA, independent schools ve Švédsku aj.). $\mathrm{V}$ ČR lze zmíněný trend nepř́mo ilustrovat například tím, že za posledních cca deset let stoupl počet soukromých základních škol dvojnásobně z 61 škol ve školním roce 2006/2007 na 124 ve školním roce 2014/2015 (MŠMT, 2016). Je přitom možné, že založení soukromé školy je dnes daleko spíše výrazem nespokojenosti rodičů se stávajícím systémem než podnikatelským záměrem nebo způsobem, jak zajistit existenci uceleným alternativním směrům vzdělávání.

Zvyšující se poptávku rodičů po vlivu na utváření školního života lze hodnotit pozitivně i negativně. Rodiče artikulací svých požadavků dávají najevo, že se alespoň do jisté míry snaží dostát své odpovědnosti za vzdělávání svého dítěte i za kvalitu jeho života i v době, kdy ho svěřují škole. Zahraniční výzkumy ukazují, že proces zapojování rodičů do vzdělávání jejich dětí se v mnoha případech ukázal jako důležitý prediktor zlepšování vzdělávacích výsledků žáků (Ma et al., 2015).

Z hlediska spravedlivých př́ležitostí je ovšem jistě relevantní obava, že někteří rodiče budou partikulárně prosazovat zájmy svých dětí, přičemž zároveň může docházet $\mathrm{k}$ poškozování zájmů dětí, o které rodiče tak intenzivně nepečují. Nemusí jít přitom o jednání záměrné, nicméně analýzy interakcí rodiny a školy z pohledu matek ukazují, že matky s nižším vzděláním se cítily při interakcích se školou spíše bezmocné, zatímco vzdělanější matky se častěji prezentovaly při komunikaci se školou jako úspěšné (Vojtíšková, 2010). Nastavování spolupráce rodiny a školy je proto do budoucna velmi důležité. 
Hledání vhodných forem, které budou přijatelné a efektivní pro všechny zainteresované, nadále zůstává velkou výzvou, protože těsné vztahy mezi rodinou a školou nemusí být za každých okolností prospěšné (Majerčíková, 2015).

Za stávající situace ale poptávka po zapojování rodičů a jejich zmocňování představuje pro školy spíše problém než vítaný proces. Český vzdělávací systém dosud neuměl v širším měřítku zavést partnerský model spolupráce rodiny a školy. Výraznější aktivity rodičů jsou považovány častěji za kverulantství než za pokus o spolupráci a učitelé je vnímají jako ohrožení své pozice profesionála (Pulišová, 2016). K tomu dochází obzvláště $\mathrm{v}$ „tradičních školách", ve kterých se učitelé brání otevřenému dialogu s rodiči (Matýsková, 2005). Naproti tomu ve školách pracujících podle programu Začít spolu, jež se cíleně orientovaly na komunikaci s rodiči, se rodiče aktivněji zapojovali do spolupráce a projevovali více zájmu o dění ve škole (Matýsková, 2005).

Předložená analýza přinesla také doklady o důležitosti triangulace metod výzkumných šetření. Z kvalitativní obsahové analýzy se kromě proměnných uplatněných $\mathrm{v}$ uzavřené otázce vynořila kategorie, která vyjadřuje potřebu rodičủ ve spolupráci se školou participovat na utváření vzdělávání jejich dětí.

Vynoření nové kategorie může poukazovat na trend, který stále výrazněji spoluutváří vzájemné nastavení vztahů mezi školou a rodinou. V širší perspektivě pak může naznačovat, že rodiče nejsou spokojeni s vývojem, který noví institucionalisté popisují jako izomorfizmus (podrobněji Dvořák, 2012). Důraz rodičů na well-being jejich dítěte, zohledňování jeho individuálních potřeb a zájem o partnerský vztah mezi školou a rodinou ukazuje, že školy, které jsou si ve svých klíčových aktivitách velice podobné a jež jsou zaměřené především na kvalitu vzdělávání, přestávají rodičům fungujícím v prostředí ve velké míře orientovaném na individualizaci dostačovat.

Teprve čas (a další zkoumání) ukáže, zda školy budou nabízet skutečně individualizovaná řešení a zda rodičům bude jejich nabídka stačit. Může se stát, že poptávka po individualizaci bude naplňována pouze na úrovni dobře viditelných a líbivých vnějších odlišujících charakteristik, které skutečnou funkcionalitu instituce významně neovlivní, a faktická poptávka po izomorfizmu bude potvrzena i z pozic rodičovských, byt' v poněkud kryptičtější formě. 


\section{Závěry}

Agregovaná přání rodičů týkající se základní školy nejsou nikterak překvapivá. Škola by měla mít dobrou pověst, měla by být v relativně malé vzdálenosti od místa bydliště či zaměstnání, ideálně v klidné a bezpečné lokalitě. Vzdělávání by pod schopným vedením měli zajištovat profesně dobře vybavení učitelé $\mathrm{v}$ hezké budově školy vybavené moderními pomůckami s integrovanou jídelnou a tělocvičnou. Na úrovni výstupů rodiče očekávají, že jejich dítě získá kvalitní vzdělání, které mu umožní pokračovat v dalším studiu, chtějí také, aby se naučilo samostatnosti a získalo dobrý vztah ke vzdělávání. Vedle kognitivních výstupů rodiče také očekávají, že se jejich dítě bude ve škole cítit dobře a bude do ní rádo chodit. Kromě vzdělávání v povinném kurikulu, ve kterém kladou důraz na výuku jazyků, rodiče očekávají, že škola zajistí program pro jejich dítě i v době mimo vyučování formou družiny a prostřednictvím velkého výběru kroužků a zájmových aktivit. Rodiče také chtějí, aby s nimi učitelé jejich dětí komunikovali, v lepším případě k nim přistupovali partnersky. Pro rodiče je důležité nejen to, co se ve škole děje, ale také jak se to děje. Jako významné kritérium rodiče popisují přístup učitelů k dětem i rodičům, tedy kvalitativní rozměr vzájemného vztahu. Očekávají, že učitelé budou $\mathrm{k}$ dětem (ale i k rodičům) vlídní a vstřícní.

Souběžné položení uzavřené a otevřené otázky rovněž poukázalo na význam pokládání otevřených otázek. Analýza otevřené otázky přinesla kvalitativně nové informace, které by kvůli standardnímu používání uzavřených otázek mohly zůstat opomenuty.

V kvalitativní části analýzy se oproti kvantitativní části vynořila nová kategorie, popsaná jako zajištování vlivu. Rodiče projevují zájem o komunikaci a spolupráci, to znamená, že chtějí získávat a vyměňovat si informace a aktivně se podílet na vzdělávání svého dítěte.

\section{Limity studie a náměty pro další výzkum}

Kromě obecnějších omezení vyplývajících z využití metody sběru dat (například uvádění sociálně žádoucích odpovědí, nereflektování rozporu mezi teoretickými úvahami o důležitých vlastnostech a praktickou volbou) má předkládaná studie i specifické limity plynoucí z charakteru zkoumaného výběru.

Závěry této studie není možné zobecňovat na všechny rodiče vzhledem ke skutečnosti, že do šetření byli zahrnuti pouze rodiče dětí, které navštěvují 
mateřskou školu. Rodiče dětí, které z různých důvodů mateřskou školu nenavštěvují, by mohli do šetření vnést dimenze, které by pravděpodobně nebyly významné ve svém rozsahu, ale mohly by naznačovat nově se objevující trendy ve výběru školy. Proto by jistě bylo přínosné soustředit se v dalším šetření na tuto do jisté míry skrytou populaci.

Další možné omezení plyne ze skutečnosti, že dotazník vyplňovaly ve významné většině př́ípadů matky dítěte. Kvưli této skutečnosti mohl zůstat opomenut názor otce, který se případně mohl výrazněji uplatnit např́íklad v závěrečných fázích procesu. Bylo by jistě ideální dotazovat se na důvody rodičủ co nejblíže vlastnímu rozhodnutí, zároveň je ale zřejmé, že různí rodiče se mohou rozhodnout $v$ různé fázi procesu, a proto by takový sběr dat nebyl možný z praktických důvodů.

Vzhledem k poměrně limitovanému počtu empirických studií zabývajících se tématem volby školy $\mathrm{v}$ ČR je možné zaměření dalších studií poměrně široké. $V$ první řadě by bylo přínosné zjistit, jak volba školy přispívá k diferenciaci, tedy zda a jakým způsobem ovlivňuje složení žáků jednotlivých škol. Jedním z př́íspěvků v tomto směru bude plánované kvantitativní zpracování dat získaných v projektu CLoSE a publikace jeho výsledků v českých odborných periodikách, které naváže na již publikované práce čerpající z dat CLoSE (např. Greger, 2015; Chvál, Felcmanová, \& Kaslová, 2015; Simonová, 2015; Straková \& Simonová, 2015). I vzhledem k prioritám vzdělávací politiky by pak bylo jistě zajímavé prozkoumat, jak výběr školy ovlivňuje dvě zásadní priority české vzdělávací politiky - efektivitu vzdělávání a rovnost př́ležitostí. Bylo by tedy žádoucí se zaměřit na prozkoumání otázky, zda a nakolik aktivní výběr školy vede k lepším vzdělávacím výsledkům žáků s různou úrovní vstupních schopností a zda přispívá ke zlepšování výsledků vzdělávání v rámci celého vzdělávacího systému.

\section{Poděkování}

Autorka děkuje doc. RNDr. Janě Strakové, Ph.D. a RNDr. Dominiku Dvořákovi, Ph.D. za cenná doporučení při tvorbě a úpravách textu. 


\section{Literatura}

Ball, S. J., \& Vincent, C. (1998). I heard it on the grapevine: „Hot“ knowledge and school choice. British Journal of Sociology of Education, 19(3), 377-400.

Borghans, L., Golsteyn, B. H. H., \& Zölitz, U. (2015). Parental preferences for primary school characteristics. The B. E. Journal of Economic Analysis \& Policy, 15(1), 85-117.

Bosetti, L., \& Pyryt, M. C. (2007). Parental motivation in school choice. Journal of School Choice, 1(4), 89-108.

Bourdieu, P., \& Passeron, J. C. (1977). Reproduction in education, society and culture. Thousand Oaks: Sage.

Burgess, S., Greaves, E., Vignoles, A., \& Wilson, D. (2015). What parents want: School preferences and school choice. Economic Journal, 125(587), 1262-1289.

Bussel, H. (1998). Parental choice of primary school: An application of Q-Methodology. The Service Industries Journal, 18(3), 135-147.

Costanza, R. (2007). Quality of life: An approach integrating opportunities, human needs, and subjective well-being. Ecological Economics, 61(2-3), 267-276.

Cucchiara, M. (2013). „Are we doing damage?” Choosing an urban public school in an era of parental anxiety. Anthropology and Education Quarterly, 44(1), 75-93.

Davies, S., \& Aurini, J. (2011). Exploring school choice in Canada: Who chooses what and why? Canadian Public Policy, 37(4), 459-477.

Denessen, E., Driessena, G., \& Sleegers, P. (2005). Segregation by choice? A study of groupspecific reasons for school choice. Journal of Education Policy, 20(3), 347-368.

Dvořák, D. (2012). Nový institucionalismus v pedagogice. Studia paedagogica, 17(2), 9-26.

Elacqua, G., \& de Gobierno, E. (2004). School choice in Chile. An analysis of parental preferences and search behavior. New York: National center for the study of privatization in Education teachers college, Columbia University.

Elo, S., \& Kyngas, H. (2008). The qualitative content analysis process. Journal of Advanced Nursing, 62(1), 107-115.

Friedman, M. (1955). The role of government in education. In R. A. Solo (Ed.), Economics and the public interest (s. 123-144). New Brunswick: Rutgers University Press.

Gavora, P. (2015). Obsahová analýza v pedagogickom výskume: pohlad na jej súčasné podoby. Pedagogická orientace, 25(3), 345-371.

Goh, E. (2009). Public education and parents: Eliciting salient beliefs using the theory of planned behaviour as a qualitative research framework. International Review on Public and Nonprofit Marketing, 6(2), 99-108.

Goldring, E. B., \& Phillips, K. J. R. (2008). Parent preferences and parent choices: The publicprivate decision about school choice. Journal of Education Policy, 23(3), 209-230.

Goldthorpe, J. H. (1996). Class analysis and the reorientation of class theory: The case of persisting differentials in educational attainment. The British Journal of Sociology, 47(3), 481-505.

Greger, D. (2015). Faktory ovlivňující rozhodování rodičů o odkladu školní docházky dítěte. In D. Greger, J. Simonová, \& J. Straková, J. (Eds.), Spravedlivý start - vyrovnávání šancí na vstupu do povinného vzdělávání (s. 96-105). Praha: Pedagogická fakulta UK v Praze. 
Hastings, J., Kane, T., \& Staiger, D. (2005). Parental preferences and school competition: Evidence from a public school choice program. NBER Working Paper 11805. Dostupné $\mathrm{z}$ http://www. nber.org/papers/w11805

Hatcher, R. (1998). Class differentiation in education: Rational choices? British Journal of Education, 19(1), 5-24.

Hsieh, H. F., \& Shannon, S. (2005). Three approaches to qualitative content analysis. Qualitative Health Research, 15(9), 1277-1288.

Chvál, M., Felcmanová, L., \& Kaslová, M. (2015). Úroveň zrakového vnímání a předmatematických dovedností u předškoláků. In D. Greger, J. Simonová, \& J. Straková (Eds.), Spravedlivý start vyrovnávání šancí na vstupu do povinného vzdělávání (s. 71-94). Praha: Pedagogická fakulta UK v Praze.

Jennings, J. L. (2010). School choice or schools' choice? Managing in an era of accountability. Sociology of Education, 83(3), 227-247.

Kebza, V., \& Šolcová, I. (2005). Koncept osobní pohody (well-being) a jeho psychologické a interdisciplinární souvislosti. In M. Blatný, J. Dosedlová, V. Kebza, \& I. Šolcová (Eds.), Psychosociální souvislosti osobní pohody (s. 9-36). Brno: Masarykova univerzita.

Kimelberg, S. M. (2014). Beyond test scores: Middle-class mothers, cultural capital, and the evaluation of urban public schools. Sociological Perspectives, 57(2), 208-228.

Kleitz, B., Weiher, G. R., Tedin, K., \& Matland, R. (2000). Choice, charter schools, and household preferences. Social Science Quarterly, 81(3), 846-854.

Kool, D. D., \& Bekkers, B. (2016). The perceived value-relevance of open data in the parents' choice of Dutch primary schools. The International Journal of Public Sector Management, 29(3), 271-287.

Krippendorff, K. (2014). Content analysis. An introduction to its methodology. Thousand Oaks: Sage.

Ma, X., Shen, J., Krenn, H. Y., Hu, S., \& Yuan, J. (2015). A meta-analysis of the relationship between learning outcomes and parental involvement during early childhood education and early elementary education. Educational Psychology Review, 28(4), 771-801.

Majerčíková, J. (2015). Sporné aspekty úzkých vzt’ahov rodiny a školy na začiatku vzdelávaní. Studia paedagogica, 20(1), 29-44.

Matýsková, D. (2005). Spolupráce rodiny a školy z pohledu rodičů a učitelů. Pedagogická orientace, 15(1), 27-36.

MŠMT. (2014). IPORTÁL ulehčí rodičưm i žákům výběr školy. Praha: Ministerstvo školství, mládeže a tělovýchovy. Dostupné z http://www.msmt.cz/ministerstvo/novinar/registr

MŠMT. (2016). Statistická ročenka školství - výkonové ukazatele. Praha: Ministerstvo školství, mládeže a tělovýchovy. Dostupné z http://www.msmt.cz/vzdelavani/skolstvi-v-cr/ statistika-skolstvi/statisticka-rocenka-skolstvi-vykonove-ukazatele

Neuendorf, K. A. (2002). The content analysis guidebook. Thousand Oaks: Sage.

Plichtová, J. (1996). Obsahová analýza a jej možnosti využitia v psychológii. Československá psychologie, 40(4), 304-314.

Pulišová, K. (2016). Neklape nám to: učitelé a rodiče žáků prvního stupně základní školy a jejich problémové vztahy. Studia paedagogica, 21(3), 167-182.

Rabušicová, M. (2004). Postavení rodičů jako výchovných a sociálních partnerů školy (shrnutí některých výsledků z výzkumného projektu). Pedagogika, 54(4), 326-341. 
Raveaud, M., \& van Zanten, A. (2007). Choosing the local school: Middle class parents' values and social and ethnic mix in London and Paris. Journal of Education Policy, 22(1), 107-124.

Reay, D., \& Lucey, H. (2000). Children, school choice and social differences. Educational Studies, 26(1), 83-100.

Schneider, M., \& Buckley, J. (2002). What do parents want from schools? Evidence from the internet. Educational Evaluation and Policy Analysis, 24(2), 133-144.

Schneider, M., Teske, P., Marschall, M., \& Roch, C. (1998). School choice and culture wars in the classroom: What different parents seek from education. Social Science Quarterly, 79(3), 489-501.

Simonová, J. (2015). Postoje rodičů k volbě základní školy. Studia paedagogica, 20(3), 69-88.

Straková, J., \& Simonová, J. (2015). Výběr základní školy v ČR a faktory, které jej ovlivňují. Sociologický časopis / Czech Sociological Review, 51(4), 587-606.

Šojdrová, M., Swart, D., \& Gabal, I. (2013). Zpráva o výsledcích výzkumu postojů rodičů žáků 5. ročníku k otázkám spravedlivého př́stupu ke vzdělávání a překonávání školního neúspěchu. Praha: ČŠI. Dostupné z http://www.csicr.cz/getattachment/1e0fd0dc-0583-4530-85c0fa7b9f4aa55d

Vojtíšková, K. (2010). Interakce rodiny a školy pohledem matek. Pedagogika, 60(2), 115-126.

Walterová, E., Černý, K., Greger, D., \& Chvál, M. (2010). Školství - věc (ne)veřejná: názory veřejnosti na školu a vzdělávání. Praha: Karolinum.

Zákon č. 561/2004 Sb., O předškolním, základním, středním, vyšším odborném a jiném vzdělávání (školský zákon). (2004). Praha: Ministerstvo vnitra České republiky. Dostupné z http:// www.mvcr.cz/sbirka/2004/sb190-04.pdf

\title{
Autorka
}

Mgr. Jaroslava Simonová, Ph.D., Univerzita Karlova, Pedagogická fakulta, Ústav výzkumu a rozvoje vzdělávání, Myslíkova 7, 11000 Praha 1, e-mail: jaroslava.simonova@pedf.cuni.cz

\section{Characteristics of a good compulsory school from the parent's point of view}

\begin{abstract}
Despite the relatively large number of papers that have been devoted to examining parental preferences in international context, there is no general consensus on what the most important for parents when choosing a school is. Usually parents value academic results, socio-economic composition of the students, communication and engagement in school life, classes with fewer students, shared values and teaching style. The aim of this paper is to describe the characteristics of a good school from the perspective of Czech parents using data collected in a longitudinal survey CLoSE from a representative sample of 2,008 parents of preschool children and compare information obtained through open-ended and close-ended questions using the methods of content analysis and descriptive statistics. Parents expect that a school
\end{abstract}


will provide their children and also themselves with personalized solutions focused not only on good academic results, but also on the best possible quality of life and that the school will enable them to participate in shaping the schooling of their children.

Keywords: school choice, compulsory school, primary school, content analysis

\section{Příloha}

Tabulka P1

Četnost a procentuální zastoupení jednotlivých kódů $v$ odpovědích rodiču na otázku: Co musí splňovat dobrá škola pro Vaše dítě? Napište prosím ty nejdůležitější věci, které se Vám vybaví.

\begin{tabular}{|c|c|c|c|c|c|c|c|}
\hline \multirow[b]{2}{*}{ Kategorie } & \multirow[b]{2}{*}{ Kód } & \multicolumn{2}{|c|}{ Vybraný kód } & \multicolumn{2}{|c|}{ Všechny kódy } & \multicolumn{2}{|c|}{ Alespoň jeden kód } \\
\hline & & Četnost & $\%$ & Četnost & $\%$ & Četnost & $\%$ \\
\hline \multirow{2}{*}{ Pozice školy } & Dostupnost & 221 & 16 & \multirow{2}{*}{58} & \multirow{2}{*}{4} & \multirow{2}{*}{287} & \multirow{2}{*}{21} \\
\hline & Pověst & 182 & 13 & & & & \\
\hline \multirow{3}{*}{$\begin{array}{l}\text { Péče mimo } \\
\text { vyučování }\end{array}$} & Družina & 102 & 7 & \multirow{3}{*}{15} & \multirow{3}{*}{1} & \multirow{3}{*}{428} & \multirow{3}{*}{31} \\
\hline & Kroužky & 333 & 24 & & & & \\
\hline & Jídelna & 117 & 9 & & & & \\
\hline \multirow{4}{*}{$\begin{array}{l}\text { Poskytování } \\
\text { kvalitního } \\
\text { vzdělávání }\end{array}$} & Výuka & 623 & 46 & \multirow{4}{*}{2} & \multirow{4}{*}{0} & \multirow{4}{*}{1109} & \multirow{4}{*}{80} \\
\hline & Výstupy & 132 & 10 & & & & \\
\hline & Učitelé & 522 & 38 & & & & \\
\hline & Vybavení & 320 & 23 & & & & \\
\hline \multirow[b]{2}{*}{$\begin{array}{c}\text { Zajištění } \\
\text { kvality života }\end{array}$} & Well-being & 694 & 51 & \multirow[b]{2}{*}{139} & \multirow[b]{2}{*}{10} & \multirow[b]{2}{*}{881} & \multirow[b]{2}{*}{64} \\
\hline & $\begin{array}{l}\text { Individuální } \\
\text { přístup }\end{array}$ & 326 & 24 & & & & \\
\hline \multirow{2}{*}{$\begin{array}{l}\text { Zajištění } \\
\text { vlivu }\end{array}$} & $\begin{array}{c}\text { Komunikace } \\
\text { s rodiči }\end{array}$ & 131 & 10 & \multirow{2}{*}{3} & \multirow{2}{*}{0} & \multirow{2}{*}{241} & \multirow{2}{*}{17} \\
\hline & $\begin{array}{c}\text { Spolupráce } \\
\text { s rodiči }\end{array}$ & 113 & 8 & & & & \\
\hline
\end{tabular}

